Marshall University

Marshall Digital Scholar

Biological Sciences Faculty Research

Biological Sciences

2011

\title{
Nitrogen Addition Shapes Soil Phosphorus Availability in Two Reforested Tropical Forests in Southern China
}

Xiankai Lu

Jiangming Mo

Frank S. Gilliam

Marshall University, gilliam@marshall.edu

Hua Fang

Feifei Zhu

See next page for additional authors

Follow this and additional works at: http://mds.marshall.edu/bio_sciences_faculty

Part of the Biology Commons, Forest Biology Commons, and the Plant Sciences Commons

\section{Recommended Citation}

Lu X, J Mo, FS Gilliam, H Fang, F Zhu, Y Fang, W Zhang, and J Huang. 2012. Nitrogen addition shapes soil phosphorus availability to nitrogen addition in two reforested tropical forests in southern China. Biotropica 44:302-311.

This Article is brought to you for free and open access by the Biological Sciences at Marshall Digital Scholar. It has been accepted for inclusion in Biological Sciences Faculty Research by an authorized administrator of Marshall Digital Scholar. For more information, please contact 


\section{Authors}

Xiankai Lu, Jiangming Mo, Frank S. Gilliam, Hua Fang, Feifei Zhu, Yunting Fang, Wei Zhang, and Juan Huang 


\title{
Nitrogen Addition Shapes Soil Phosphorus Availability in Two Reforested Tropical Forests in Southern China
}

\author{
Xiankai Lu', Jiangming Mo ${ }^{1,4}$, Frank S. Gilliam², Hua Fang ${ }^{3}$, Feifei Zhu', Yunting Fang ${ }^{1}$, Wei Zhang ${ }^{1}$, and Juan Huang ${ }^{1}$ \\ ${ }^{1}$ Key Laboratory of Vegetation Restoration and Management of Degraded Ecosystems, South China Botanical Garden, Chinese Academy of \\ Sciences, Guangzhou, 510650, China \\ ${ }^{2}$ Department of Biological Sciences, Marshall University, Huntington, West Virginia, 25755-2510, U.S.A. \\ ${ }^{3}$ Guangzhou Institute of Geography, Guangzhou, Guangdong, 510070, China
}

\section{ABSTRACT}

Scant information is available on how soil phosphorus $(\mathrm{P})$ availability responds to atmospheric nitrogen (N) deposition, especially in the tropical zones. This study examined the effect of $\mathrm{N}$ addition on soil $\mathrm{P}$ availability, and compared this effect between forest sites of contrasting land-use history. Effects of $\mathrm{N}$ addition on soil properties, litterfall production, $\mathrm{P}$ release from decomposing litter, and soil $\mathrm{P}$ availability were studied in a disturbed (reforested pine forest with previous understory vegetation and litter harvesting) and a rehabilitated (reforested mixed pine/broadleaf forest with no understory vegetation and litter harvesting) tropical forest in southern China. Experimental $\mathrm{N}$-treatments (above ambient) were the following: Control (no $\mathrm{N}$ addition), $\mathrm{N} 50$ (50 kg N ha ${ }^{-1} \mathrm{yr}^{-1}$ ), and $\mathrm{N} 100$ $\left(100 \mathrm{~kg} \mathrm{~N} \mathrm{ha}{ }^{-1} \mathrm{yr}^{-1}\right)$. Results indicated that $\mathrm{N}$ addition significantly decreased soil $\mathrm{P}$ availability in the disturbed forest. In the rehabilitated forest, however, soil $\mathrm{P}$ availability was significantly increased by $\mathrm{N}$ addition. Decreases in soil $\mathrm{P}$ availability may be correlated with decreases in rates of $\mathrm{P}$ release from decomposing litter in the $\mathrm{N}$-treated plots, whereas the increase in soil $\mathrm{P}$ availability was correlated with an increase in litterfall production. Our results suggest that response of soil $\mathrm{P}$ availability to $\mathrm{N}$ deposition in the reforested tropical forests in southern China may vary greatly with temporal changes in tree species composition and soil nutrient status, caused by different land-use practices.

Abstract in Chinese is available in the online version of this article.

Key words: land-use history; litter decomposition; nitrogen addition; nitrogen deposition; phosphorus availability; phosphorus release; reforested forest; tropical forests.

Nitrogen (N) Deposition has greatly ALtered $\mathrm{N}$ CyCling at regional and global scales (Galloway et al. 2004). Elevated N deposition has threatened ecosystem health and services through acidification and eutrophication (Sala et al. 2000, Matson et al. 2002, Bobbink et al. 2010, Lu et al. 2010) and increased susceptibility to secondary stress (Gilliam 2006, Bobbink et al. 2010). Excess N can also interfere with the ability of trees to resorb nutrients that affect plant fitness (May et al. 2005). Meanwhile, because of the tight stoichiometry of macronutrients (e.g., C:N:P ratios) and phosphorus (P) limitation that is common in terrestrial ecosystems (Reiners 1986, McGroddy et al. 2004a, Vitousek et al. 2010), N deposition may further creates imbalances in energy flow and nutrient cycling (Reich \& Oleksyn 2004, McGroddy et al. 2004a, Pregitzer et al. 2008, Zak et al. 2008). Considering that P is an essential limiting macronutrient in terrestrial ecosystems (Schlesinger 1997, Vitousek et al. 2010), studies on soil $\mathrm{P}$ availability under varying levels of $\mathrm{N}$ deposition will further our understanding on how $\mathrm{N}$ deposition affects ecosystem health and services.

Many reports suggest that $\mathrm{N}$ deposition significantly increases the availability of soil N (Vesterdal \& Raulund-Rasmussen

Received 11 January 2011; revision accepted 18 June 2011.

${ }^{4}$ Corresponding author; e-mail: mojm@scib.ac.cn

This article was published online on 31 October 2011. An error was subsequently identified. This notice is included in the online and print versions to indicate that both have been corrected on 14 November 2011.
2002, Lu et al. 2009, Corre et al. 2010), increases aboveground carbon sequestration (Thomas et al. 2010) and belowground carbon stock (Cusack et al. 2011), and induces P limitation (Gradowski \& Thomas 2006, Gress et al. 2007, Braun et al. 2010, Vitousek et al. 2010) in forest ecosystems. Little information is available on how soil $\mathrm{P}$ availability responds to atmospheric $\mathrm{N}$ deposition, especially in tropical regions (Vesterdal \& RaulundRasmussen 2002, Mo et al. 2007, Braun et al. 2010).

In tropical forest ecosystems, $\mathrm{P}$ is generally believed to be the most limiting element (Vitousek 1984), and P availability plays an important role in net primary productivity (NPP), organic matter decomposition, and soil carbon sequestration (Matson et al. 1999, Cleveland \& Townsend 2006). Moreover, soil carbon sequestration under elevated $\mathrm{CO}_{2}$ may be constrained by $\mathrm{P}$ availability in tropical forest ecosystems; thus, anthropogenic $\mathrm{N}$ deposition can further diminish carbon sequestration (Van Groenigen et al. 2006, Kaspari et al. 2008). Although this is generally true for primary forests, it is less clear for secondary tropical forests. For example, evidence suggests that early successional forests following agricultural abandonment on highly weathered lowland tropical soils exhibit conservative $\mathrm{N}$-cycling properties similar to their temperate forest counterparts (Davidson et al. 2007). Indeed, further examination of $\mathrm{N}$ fertilizer studies has also suggested that $\mathrm{N}$ limitation of NPP in terrestrial ecosystems is globally distributed (Lebauer \& Treseder 2008). 
In tropical soils, available P mainly originates from weathering of parent material and biologic processes. Once weathering ceases to provide significant inputs of $\mathrm{P}$, vegetation largely depends on the recycling of $\mathrm{P}$ through biologic processes, such as litter decomposition (Walker \& Syers 1976, Tiessen et al. 1994, McGroddy et al. 2004b). The addition of exogenous $\mathrm{N}$ to the soil-litter subsystem has shown variable effects on the rate of litter decomposition in forest ecosystems (Vitousek 1998, Knorr et al. 2005, Mo et al. 2006), and thus, potentially, the availability of phosphorus.

Rates of $\mathrm{N}$ deposition to Chinese tropical and subtropical forests have increased in recent years, largely due to increased agriculture and industrialization. Liu et al. (2011) reported that emissions of reactive $\mathrm{N}$ increased from $1980\left(7 \mathrm{Tg} \mathrm{N} \mathrm{yr}^{-1}\right)$ to 2005 (20 $\mathrm{Tg} \mathrm{N} \mathrm{yr}^{-1}$ ) in China. Lü \& Tian (2007) concluded that total $\mathrm{N}$ deposition rates are highest $\left(65 \mathrm{~kg} \mathrm{~N} \mathrm{ha}^{-1} \mathrm{yr}^{-1}\right)$ in south-central China, with a mean rate of $19 \mathrm{~kg} \mathrm{~N} \mathrm{ha}^{-1} \mathrm{yr}^{-1}$, which is higher than that for most of North American and Europe, where $\mathrm{N}$-mediated threats to forest ecosystem health have been suggested (Bobbink et al. 2010; Percy \& Ferretti 2004).

Many primary forests in China have been deforested during the past several centuries (Wang et al. 1982, Liu et al. 2000, Li 2004), with only two percent of the nation's total forest resources remaining intact (Liu et al. 2000). Attempts to reverse land degradation have been made in many subtropical and tropical regions of China, with extensive areas having been reforested with native pine species (e.g., Pinus massoniana Lamb) to prevent further degradation of the landscape. Although cutting of the trees is usually prohibited, harvesting of understory vegetation and litter is often allowed to satisfy fuel needs of local people (Brown et al. 1995, Mo et al. 1995, 2003). These reforested stands are often referred to as disturbed forests (having experienced understory vegetation and litter removal) and rehabilitated forests (reforested without such removal) (Mo et al. 2003). Reforested areas cover more than half of the total forested regions of subtropical and tropical China (Brown et al. 1995, Mo et al. 2003, SFA 2007). Despite this, the interactive effects of $\mathrm{N}$ deposition and land-use changes on element cycling are poorly known (Mo et al. 2003, 2007).

The objective of our present study was to examine the effects of $\mathrm{N}$ addition on soil $\mathrm{P}$ availability and to compare these effects between reforested sites of different land-use history. We have previously reported that $\mathrm{N}$ addition significantly suppressed release rate of $\mathrm{P}$ from decomposing litter in the disturbed and the rehabilitated forests in southern China during the first $24 \mathrm{mo}$ (July 2003 to June 2005) of a $\mathrm{N}$ fertilization experiment (Mo et al. 2007), suggesting that soil P availability may decrease with increased $\mathrm{N}$ deposition. Accordingly, we hypothesize that soil $\mathrm{P}$ availability in both disturbed and rehabilitated forests would be reduced by continued $\mathrm{N}$ addition.

\section{METHODS}

Site DesCription.- This study was conducted in the Dinghushan Biosphere Reserve, which is central Guangdong Province in southern China $\left(112^{\circ} 10^{\prime} \mathrm{E}, 23^{\circ} 10^{\prime} \mathrm{N}\right)$, and occupies an area of approximately 1200 ha. Three forest types occur in the reserve: monsoon evergreen broadleaf forest (mature forest), mixed pine/ broadleaf forest (rehabilitated forest), and pine forest (disturbed forest). The reserve has a monsoon climate, and is located in a tropical moist forest life zone (sensu Holdridge 1967). The mean annual rainfall of $1927 \mathrm{~mm}$ has a distinct seasonal pattern, with 75 percent falling from March to August, and only 6 percent from December to February (Huang \& Fan 1982). Annual average relative humidity is 80 percent. Mean annual temperature is $21.0^{\circ} \mathrm{C}$, with an average temperature of the coldest month (January) and hottest (July) of $12.6^{\circ} \mathrm{C}$ and $28.0^{\circ} \mathrm{C}$, respectively (Huang \& Fan 1982). This region has been experiencing high ambient $\mathrm{N}$ deposition (21-38 $\mathrm{kg} \mathrm{N} \mathrm{ha}^{-1} \mathrm{yr}^{-1}$ as inorganic $\mathrm{N}$ in bulk precipitation), at least since 1990s (Huang et al. 1994, Zhou \& Yan 2001, Mo et al. 2002, Fang et al. 2008). Fang et al. (2008) estimated wet deposition $\mathrm{N}$ as 34 and $32 \mathrm{~kg} \mathrm{~N} \mathrm{ha}^{-1} \mathrm{y}^{-1}$ in 2004 and 2005, respectively.

We selected two types of forest for this study: a rehabilitated forest and a disturbed forest (Mo et al. 2006, Lu et al. 2011). The two forest types are about $4 \mathrm{~km}$ from each other, both originating from pine planting following clear-cutting in the 1930s, with sites being heavily eroded and degraded (Wang et al. 1982, Mo et al. 1995, 2003). In addition, the disturbed forest was under continuous land-use pressure (particularly harvesting of understory vegetation and litter) from 1930 to 1998. As a result, the tree layer remained dominated by $P$. massoniana (Brown et al. 1995, Mo et al. 1995, 2003). In contrast, lack of such harvesting in the rehabilitated forest has allowed colonization from natural dispersal of regional broadleaf species (mainly Schima superba Chardn. \& Champ), and has changed overstory composition. As a result, the tree layer has become dominated by $P$. massoniana and some broadleaf species (Mo et al. 2003, 2007).

We established our research sites in both forests in 2002. A pretreatment assessment conducted in June 2003 revealed that the major tree canopy species of the rehabilitated forest were P. massoniana and S. superba; disturbed forest was dominated by P. massoniana (Table 1). The soils in both types of forest are oxisols with variable depths (Brown et al. 1995, Mo et al. 2003).

EXPERIMENTAL TREATMENTS.-Nitrogen addition experiments were initiated in both forest types in July 2003. Three replicates of each of three $\mathrm{N}$ addition treatments were established in both rehabilitated and disturbed forests: Control (without $\mathrm{N}$ added), N50 (50 kg N ha $\left.\mathrm{yr}^{-1}\right)$, and N100 (100 kg N ha $\left.\mathrm{yr}^{-1}\right)$. A total of $18,20-\mathrm{m} \times 20-\mathrm{m}$ plots were established, nine in each of rehabilitated and disturbed forests, with each plot surrounded by a $>10$ $\mathrm{m}$ wide buffer strip. Field plots and treatments were laid out randomly. Ammonium nitrate $\left(\mathrm{NH}_{4} \mathrm{NO}_{3}\right)$ solution was sprayed monthly by hand onto the forest floor as 12 equal applications. In each plot, fertilizer was weighed, mixed with $20 \mathrm{~L}$ of water, and applied below the canopy using a backpack sprayer. Two passes were made across each plot to ensure an even distribution of fertilizer. The Control plots received $20 \mathrm{~L}$ water with no $\mathrm{N}$ added.

FIELD SAMPLING.-In both disturbed and rehabilitated forests, three litterfall traps $(0.5 \mathrm{~m} \times 0.5 \mathrm{~m})$ with a mesh size of $1 \mathrm{~mm}$ 
TABLE 1. Indices of the tree layer in a disturbed and a rehabilitated tropical forest at Dinghushan Biosphere Reserve in southern China. The survey was conducted in 2003, and the area was $1800 \mathrm{~m}^{2}$ for each forest. All trees were recorded when the dbh (diameter at breast height) $\geq 2.5 \mathrm{~cm}$.

\begin{tabular}{lccccc}
\hline & $\begin{array}{c}\text { Density } \\
(\mathrm{stem} / \mathrm{ha})\end{array}$ & $\begin{array}{c}\text { Mean }(\mathrm{m}) \\
\text { height }\end{array}$ & $\begin{array}{c}\text { Mean } \\
(\mathrm{cm}) \mathrm{dbh}\end{array}$ & $\begin{array}{c}\text { Basal } \\
\text { area } \\
\left(\mathrm{m}^{2} / \mathrm{ha}\right)\end{array}$ & $\begin{array}{c}\text { Relative } \\
\text { area }\end{array}$ \\
$\begin{array}{l}\text { Species } \\
(\%) \text { basal }\end{array}$ \\
\hline $\begin{array}{l}\text { Disturbed forest } \\
\text { Pinus massoniana }\end{array}$ & 354 & 7.4 & 17.7 & 10.5 & 95.3 \\
Schima superba & 38 & 4.5 & 4.0 & 0.1 & 0.4 \\
Other plants & 188 & 3.9 & 3.9 & 0.5 & 4.2 \\
Total & 580 & & & 11.1 & 100.0 \\
Rehabilitated forest & & & & & \\
Schima superba & 1158 & 4.6 & 6.4 & 5.5 & 54.3 \\
Pinus massoniana & 96 & 8.0 & 21.9 & 4.1 & 40.4 \\
Other plants & 150 & 3.9 & 4.4 & 0.5 & 5.3 \\
Total & 1404 & & & 10.1 & 100.0 \\
\hline
\end{tabular}

Note: Data are cited from Lu et al. (2011). [This table was corrected after publication.]

were placed randomly in each plot (nine litter traps per treatment) about $0.5 \mathrm{~m}$ above the ground surface at the start of the study (27 August 2003). These traps were emptied once every month during the entire study period from September 2003 to August 2007.

To quantify responses of litterfall decomposition rates to $\mathrm{N}$ addition in both forests, we selected identical litter for all treatments: S. superba and Castanopsis chinensis (Sprengel) Hance, which are the main native tree species and contribute most of the leaf litter in forest ecosystems of Dinghushan Biosphere Reserve (Mo et al. 2006, Fang et al. 2007). Fresh leaf litter was collected using litter traps and nylon mesh, which were laid on the forest floor under the trees in the study sites during May and June 2005. All litter materials were air-dried to a constant weight and mixed before filling the mesh bags. Litter bags were made of $25 \times 25 \mathrm{~cm}$ polyvinyl plastic with $0.5 \mathrm{~mm}$ mesh size at the bottom and $2 \mathrm{~mm}$ mesh size at the top (Fang et al. 2007). Six subsamples (about $12.0 \mathrm{~g}$ per subsample) from each kind of litter type were analyzed for initial litter chemistry (total C, N, and P concentrations). There was no significant difference between litter types in initial litter chemistry (Table 2).

Bags were filled with $12.0 \mathrm{~g}$ air-dried mass, and only one litter type was put in each bag. On 18 October 2005 (approx.
26 mo after first N-treatment), these litter bags were evenly distributed among each plot of the two forests. Litter bags were randomly retrieved from each string at 3-mo intervals. Two litter bags of each species were collected from each plot at each sampling time (Fang et al. 2007).

Mineral soils $(0-10 \mathrm{~cm}$ ) were sampled in April 2007 (after 46 mo of continuous N-treatment) to determine soil available P. In each plot, four bulked samples, each the composite of five randomly distributed cored $(2.5 \mathrm{~cm}$ diam $)$ soil samples, were collected (a total of 72 samples in two forests).

LABORATORY PROCEDURES.-For monthly collections from litterfall traps, we dried each litter component to a constant weight at $80^{\circ} \mathrm{C}$. Litter collected from litter bags was cleaned of ingrown roots and other contaminants and oven-dried in paper bags first to a constant weight at $45^{\circ} \mathrm{C}$. After drying, the content of each bag was weighed individually. Subsamples of dried litter was grounded and analyzed for $\mathrm{P}$ concentration. In addition, initial litter $\mathrm{C}, \mathrm{N}$, and $\mathrm{P}$ concentrations of the selected tree species were also measured: carbon was measured using dichromate oxidation before titration with $\mathrm{Fe}^{2+}$ solution, and $\mathrm{N}$ and $\mathrm{P}$ were analyzed colorimetrically after digestion (Dong 1996).

Soils were sieved $(2 \mathrm{~mm})$ to remove plant residues (including roots), and mixed thoroughly by hand. Soil-available $\mathrm{P}$ was determined by adding an acid-ammonium fluoride extracting solution (0.025 $\mathrm{mol} \mathrm{L}^{-1} \mathrm{HCl}+0.03 \mathrm{~mol} \mathrm{~L}^{-1} \mathrm{NH}_{4} \mathrm{~F}$ ) (Bray \& Kurtz 1945). To explore possible mechanisms for changes of soil $\mathrm{P}$, we also determined soil $\mathrm{pH}$ (soil: water $=1: 2.5$ ), exchangeable $\mathrm{Al}$ and $\mathrm{Fe}$, and soil organic carbon (SOC). Soil $\mathrm{Al}$ and $\mathrm{Fe}$ were extracted with $1 \mathrm{~mol} \mathrm{~L}{ }^{-1} \mathrm{KCl}(10: 1$, solution: soil), and were determined using ICP optical emission spectrometer (Waltham, MA, U.S.A.). SOC was measured using dichromate oxidation before titration with $\mathrm{Fe}^{2+}$ solution (Liu et al. 1996). Subsamples of all materials (soil or litter) were dried at $105^{\circ} \mathrm{C}$ to a constant weight (at least $24 \mathrm{hr}$ ), and all results are reported on an oven-dry weight basis.

DATA ANALYSES.-Repeated measures analysis of variance (ANOVA) with Tukey's honest significant difference (Tukey's HSD) test was performed to examine the overall effects of $\mathrm{N}$ addition on the litterfall production of each component among treatments for the study period from September 2003 to August 2007 in each type of the forests. This analysis also examined overall effects of $\mathrm{N}$ addition on the $\mathrm{P}$ content of decomposing litter (values of $X t / X o$ ) among treatments for the study period from October 2005 to September 2006 in two forests, respectively. Here, $X o$ is the initial mass $(\mathrm{g} / \mathrm{bag})$ and $X t$ is the mass remaining $(\mathrm{g} / \mathrm{bag})$ at

TABLE 2. Initial litter chemistry of the selected tree species in two tropical forests in southern China.

\begin{tabular}{|c|c|c|c|c|c|c|}
\hline Species/litter type & $\mathrm{C}\left(\mathrm{mg} \mathrm{g}^{-1}\right)$ & $\mathrm{N}\left(\mathrm{mg} \mathrm{g}^{-1}\right)$ & $\mathrm{P}\left(\mathrm{mg} \mathrm{g}^{-1}\right)$ & $\mathrm{C} / \mathrm{N}$ & $\mathrm{C} / \mathrm{P}$ & $\mathrm{N} / \mathrm{P}$ \\
\hline Schima superba & $445(8)^{a}$ & $14.8(0.3)^{\mathrm{a}}$ & $0.56(0.01)^{\mathrm{a}}$ & $30.2(0.9)^{\mathrm{a}}$ & $802(20)^{a}$ & $26.6(0.8)^{a}$ \\
\hline
\end{tabular}

Note: Values are means with $1 \mathrm{SE}$ in parentheses, $N=6$; Within a single column in a given species sharing the same letter are not significant different at $P<0.05$ level. The element ratios are given by mass:mass. 
time $\mathrm{t}$ (October 2005 to September 2006). Litter P content was calculated by multiplying $\mathrm{P}$ concentration by mass remaining (Fang et al. 2007, Mo et al. 2007). The exponential model (Xo/ $X t=\mathrm{e}^{-\mathrm{kt}}$, Olson 1963) was fit to the data using least squares regression of the natural logarithm of mean litter $\mathrm{P}$ fraction remaining (Kuperman 1999, Mo et al. 2006), where 'e' is the base of natural logarithm, and ' $\mathrm{k}$ ' is the litter $\mathrm{P}$ decomposition coefficient. We used independent sample $t$-tests to determine differences in soil $\mathrm{P}$ availability between the control plots of two forests, and differences in initial litter chemistry between the selected tree species. In addition, we conducted the planned contrast analysis to test differences between control plots and $\mathrm{N}$-treatment plots. All statistical analyses were conducted using SPSS 13.0 (SPPS, Chicago, III, Illinois, U.S.A.) for Windows.

The statistical design of this study includes simple pseudoreplication, a common characteristic whole stand-level forest ecosystem studies, with each forest representing an experimental condition with a sample size of one (Hurlbert 1984); thus, our data should be interpreted with that in mind. It is our contention, however, that any effects we report are related to site history, rather than pre-existing differences among stands, given the close similarities among watersheds in several 'site' variables such as soil texture, soil organic matter, and extractable nutrients ( $\mathrm{Lu}$ et al. 2011).

\section{RESULTS}

Soll Response to N ADDition.-Available soil P of the Control plots was significantly higher in the disturbed forest $\left(0.43 \pm 0.04 \mathrm{mg} \mathrm{kg}^{-1}\right.$ soil) than that in the rehabilitated forest $\left(0.25 \pm 0.02 \mathrm{mg} \mathrm{kg}^{-1}\right.$ soil $)\left(F_{[4,6]}=6.04, F\right.$ value with degrees of freedom and number of data, respectively, the same below; $P=0.001)$. Effects of $\mathrm{N}$ addition on soil $\mathrm{P}$ availability varied depending on the rates of $\mathrm{N}$ addition and forest types (Fig. 1). In the disturbed forest, both $\mathrm{N}$-treatments significantly decreased soil available $\mathrm{P}(P=0.049$ and 0.035 in the N50 and N100 plots, respectively). In contrast, soil available $\mathrm{P}$ increased with increasing rate of $\mathrm{N}$ addition in the rehabilitated forest, a difference that was significant between the Control and the N100 plots $(P=0.001)$.

Nitrogen addition did not significantly affect $(P>0.05)$ soil $\mathrm{pH}$, soil SOC, or extractable $\mathrm{Al}$ and $\mathrm{Fe}$ in either forest (Table 3). Further analysis showed that there was no significant correlation between soil available $\mathrm{P}$ and any of the above variables of soil properties (data not shown).

Phosphorus RELEASE From DECOMPOSING LITTER UNDER $\mathrm{N}$ ADDITION.-Temporal patterns of $\mathrm{P}$ content in decomposing litter were similar, decreasing exponentially with time in both forests and across all treatments (Table 4; Fig. 2). In the disturbed forest, rate of litter $\mathrm{P}$ loss decreased with increasing $\mathrm{N}$-treatment levels for both types of litter. Litter P decomposition coefficients (k) were in the order: Control (0.51) > N50 (0.35) > N100 (0.34) for S. superba, and Control (0.79) > N50 (0.68) > N100 (0.64) for $C$. chinensis (Table 4). The difference between Control and $\mathrm{N} 50 / \mathrm{N} 100$ plots was significant for $S$. $\operatorname{superba}\left(F_{[2,6]}=25.6\right.$,

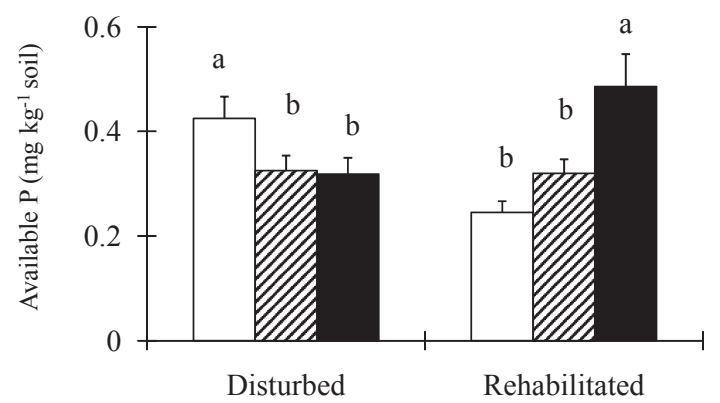

Forests

$\square$ Control $\square \mathrm{N} 50 \quad \square \mathrm{N} 100$

FIGURE 1. Effects of $\mathrm{N}$ addition on soil $\mathrm{P}$ availability in a disturbed and a rehabilitated tropical forest in southern China. Bars indicate +1 SE. Mean values sharing the same letter are not significantly different among treatments at $P<0.05$ within a forest $(N=3)$. Mineral soils $(0 \sim 10 \mathrm{~cm})$ were sampled in April 2007 (after 46 mo of continuous $\mathrm{N}^{*}$-treatment). Monthly applications of $\mathrm{NH}_{4} \mathrm{NO}_{3}$ began in July 2003 .

TABLE 3. Effects of $N$ addition on soil $p H, S O C$, and extractable $A l$ and $F e$ in the disturbed and rehabilitated forests. Data indicate means with S.E. in parenthesis. Mineral soils $(0 \sim 10 \mathrm{~cm}$ ) were sampled in April 2007 (after 46 mo of continuous $N$-treatment).

\begin{tabular}{lclll}
\hline N-treatments & $\mathrm{pH}$ & $\mathrm{Al}(\mathrm{mg} / \mathrm{kg})$ & $\mathrm{Fe}(\mathrm{mg} / \mathrm{kg})$ & $\mathrm{SOC}(\mathrm{g} / \mathrm{kg})$ \\
\hline Disturbed forest & & & & \\
Control & $4.00(0.03)$ & $338.36(51.37)$ & $12.19(1.85)$ & $23.63(3.86)$ \\
N50 & $3.95(0.02)$ & $381.93(30.02)$ & $15.84(1.57)$ & $24.60(0.22)$ \\
N100 & $3.97(0.01)$ & $349.60(36.19)$ & $11.67(1.61)$ & $24.64(0.21)$ \\
Rehabilitated forest & & & \\
Control & $3.92(0.03)$ & $395.38(23.05)$ & $16.51(2.77)$ & $19.70(1.51)$ \\
N50 & $3.88(0.02)$ & $400.60(3.51)$ & $16.73(0.82)$ & $20.28(3.10)$ \\
N100 & $3.86(0.03)$ & $382.00(39.50)$ & $17.90(0.35)$ & $21.85(1.96)$ \\
\hline
\end{tabular}

$P=0.001)$, but not for $C$. chinensis $\left.\left(F_{[2,}, 6\right]=2.8, P=0.141\right)$ (Table 4). The effect of $\mathrm{N}$ addition on litter $\mathrm{P}$ loss, however, depended on the length of litter exposure and the litter type $\left(F_{[8}\right.$, ${ }_{48]}=2.3$ for the interaction between time*litter type*treatment, $P=0.034)$. After the first $6 \mathrm{mo}$, there was no significant difference between treatments for $S$. superba, but a significant difference was found between treatments in the remaining sampling dates $\left(F_{[8,24]}=13.9\right.$ for the interaction between time*treatment, $P<0.001$ ) (Fig. 2A). In contrast, a significant difference between treatments was found only on the third sampling date for $C$. chinensis $\left(F_{[8,24]}=4.1\right.$ for the interaction between time*treatment, $P=0.003$ ) (Fig. 2B). Repeated measures ANOVA showed that both rates of $\mathrm{N}$ addition significantly reduced the loss of $\mathrm{P}$ relative to the Control plots over the entire decomposition period for $S$. superba $\left(F_{[2,6]}=27.8, P=0.001\right)$, but not significant for C. chinensis $\left(F_{[2,6]}=1.7, P=0.265\right)$.

In the rehabilitated forest, there was no significant difference in $\mathrm{P}$ content of decomposing litter between treatments in any 
TABLE 4. Litter P decomposition (loss) coefficients (k) for the selected tree species in two reforested tropical forests in southern China.

\begin{tabular}{|c|c|c|c|c|c|c|c|c|c|}
\hline Forest type/litter type & \multicolumn{3}{|c|}{ Control } & \multicolumn{3}{|c|}{ N50 } & \multicolumn{3}{|c|}{ N100 } \\
\hline Schima superba & $0.51(0.02)^{\mathrm{a}}$ & $0.97(0.01)$ & $0.003(0.001)$ & $0.35(0.00)^{\mathrm{b}}$ & $0.96(0.00)$ & $0.004(0.001)$ & $0.34(0.03)^{\mathrm{b}}$ & $0.87(0.02)$ & $0.022(0.004)$ \\
\hline Castanopsis chinensis & $0.79(0.02)^{\mathrm{a}}$ & $0.96(0.00)$ & $0.003(0.000)$ & $0.68(0.08)^{\mathrm{a}}$ & $0.97(0.01)$ & $0.003(0.002)$ & $0.64(0.02)^{\mathrm{a}}$ & $0.99(0.01)$ & $0.001(0.001)$ \\
\hline \multicolumn{10}{|l|}{ Rehabilitated } \\
\hline
\end{tabular}

Note: Values are means with $1 \mathrm{SE}$ in parentheses, $N=3$; Decomposition coefficients $(\mathrm{k})$, coefficients of determination $\left(\mathrm{r}^{2}\right)$, and $P$-values are based on a single negative exponential model; Different letter within a single column indicate significant difference at $P<0.01$.

\section{Disturbed forest}
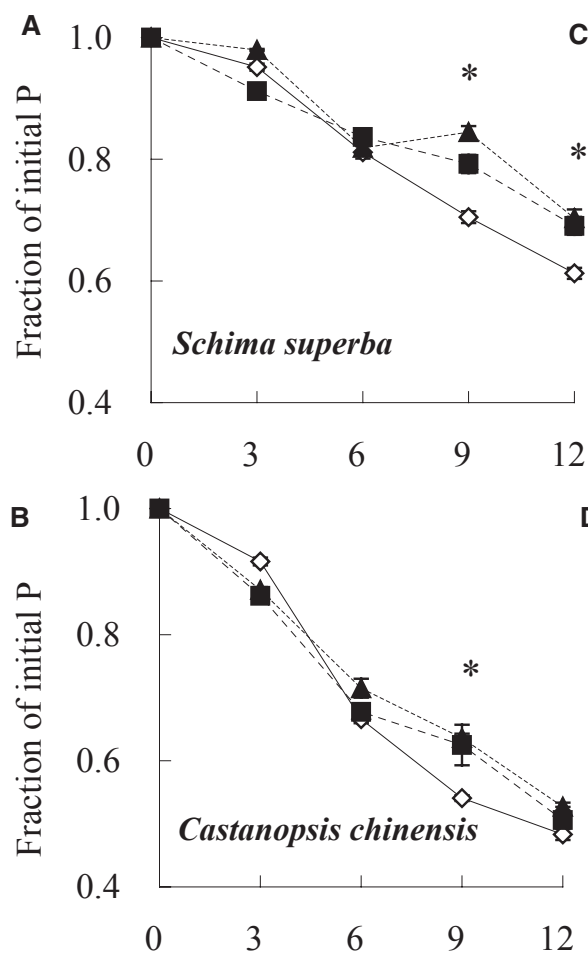

$\diamond$ Control

\section{Rehabilitated forest}

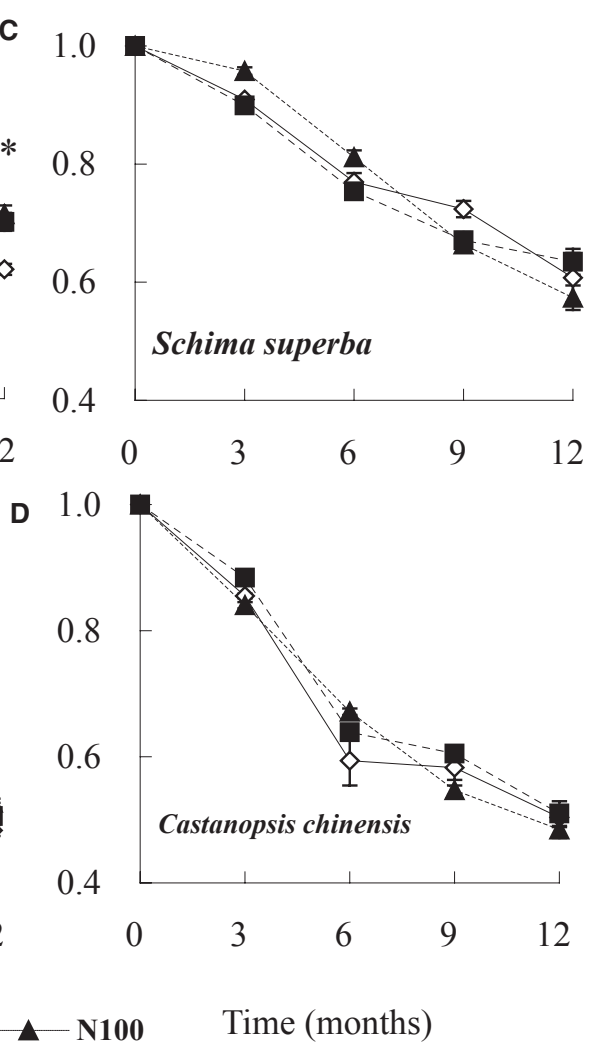

FIGURE 2. Changes in P content of decomposing litter in a disturbed and a rehabilitated tropical forest in southern China from October 2005 to September 2006. Bars indicate \pm 1 SE. Asterisk $\left(^{*}\right)$ indicates significant difference between Control plots and $\mathrm{N}$-treatment at $P<0.05$ level using planned contrast analysis $(N=3)$.

sampling dates and any litter type (Fig. 2C-D). The interaction between time and treatment was not significant in $\mathrm{P}$ loss for both types of litter $\left(F_{[8,24]}=1.7\right.$ for $S$. superba, $P=0.259$; and $F_{[8 \text {, }}$ ${ }_{24}=0.4$ for $C$. chinensis, $\left.P=0.665\right)$. As a result, repeated measures ANOVA showed that $\mathrm{N}$ addition had no significant effect on $\mathrm{P}$ content of the decomposing litter for both types of litter over the entire decomposition period $\left(F_{[2,6]}=0.7\right.$ for $S$. superba, $P=0.541 ; F_{[2,6]}=1.7$ for $C$. chinensis, $P=0.253$; Fig. $\left.2 \mathrm{C}-\mathrm{D}\right)$. This is also confirmed by comparison of litter $\mathrm{P}$ loss coefficients (Table 4). 
RESPONSE OF LITTERFALL PRODUCTION TO N ADDITION.-Total litter fall varied seasonally, across years, and between forests over the 4-yr period (Fig. 3). Mean monthly litterfall in the Control plots was higher in the growing season (April-September) than that in the winter (December-February) in both forests. Contribution of leaf litter to total litter was about 75 and 80 percent in the disturbed and rehabilitated forests, respectively, during the study period (data not shown).

Repeated measures ANOVA revealed no significant effects of $\mathrm{N}$ additions on total litterfall production in the disturbed forest during the study period $\left(F_{[2,6]}=3.2, P=0.112\right)$. In the rehabilitated forest, however, $\mathrm{N}$ addition increased total litter production, which was significantly $\left.\left(F_{[2,}, 6\right]=7.7, P=0.022\right)$ higher in the $\mathrm{N}$-treatment plots than that in the Control plots for the last $2 \mathrm{yr}$ of the experiment (Fig. 3).

\section{DISCUSSION}

Our results demonstrate that $\mathrm{N}$ addition significantly altered availability of soil $\mathrm{P}$ in two forests. Based on evidence published in the literature, several mechanisms are possible in explaining this response: (1) changes in soil $\mathrm{pH}$, subsequently altering geochemical equilibrium on sorption and precipitation of $\mathrm{P}$ with $\mathrm{Al}$ and Fe (Mccormick \& Borden 1972, Sherman et al. 2006, Weand et al. 2010); (2) changes in the production of low molecularweight organic acids that would affect the release of inorganic $\mathrm{P}$ associated with Al and Fe (Zou et al. 1995, Singh \& Amberger 1998, Harrold \& Tabatabai 2006); (3) changes in rates of litterfall and/or decomposition (Zou et al. 1995, Mo et al. 2007); (4) changes in microbial immobilization of solution P (Zou et al. 1995); and (5) changes in quality and quantity of organic inputs
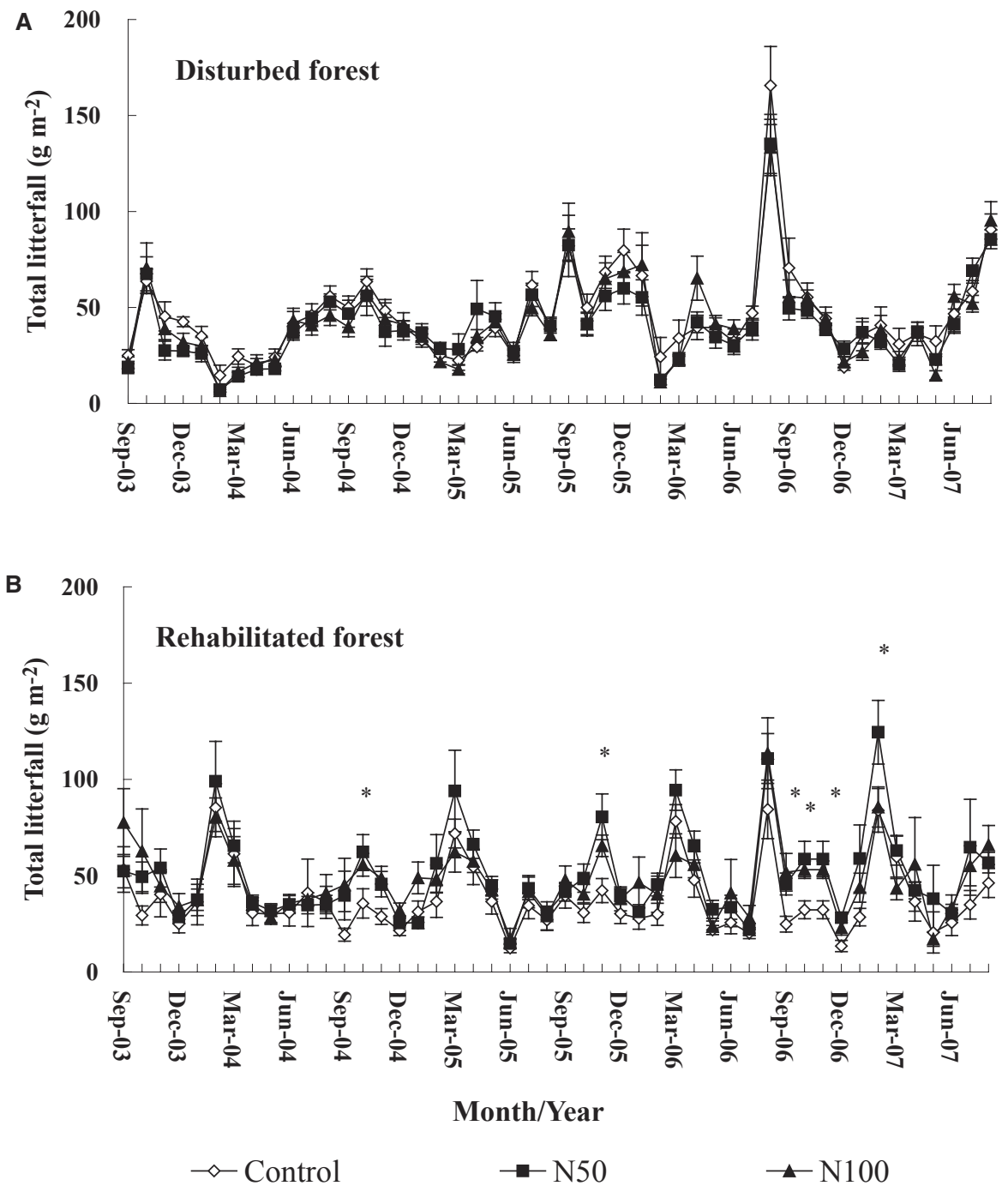

FIGURE 3. Monthly patterns of total litterfall production in a disturbed and a rehabilitated tropical forest in southern China from September 2003 to August 2007. Bars indicate \pm 1 SE. Asterisk $\left(^{*}\right)$ indicates significant difference between Control plots and $\mathrm{N}$-treatment at $P<0.05$ level using planned contrast analysis $(N=3)$. 
(Zou et al. 1995, Weand et al. 2010). In addition, increased N supply may affect mycorrhizal association and phosphatase activity, which play a very important role in $\mathrm{P}$ availability and uptake by forest trees (Olander \& Vitousek 2000, Avis et al. 2003, Braun et al. 2010, Fujita et al. 2010, Weand et al. 2010). Among these, the first is mostly accepted, especially in the acidified ecosystems; however, it is not likely to be operating in our study, considering that soil $\mathrm{pH}$ did not vary among $\mathrm{N}$-treatments (Table 3).

Data support our hypothesis that soil $\mathrm{P}$ availability in the disturbed forest may be reduced by continued $\mathrm{N}$ addition, similar to several other studies, showing that $\mathrm{N}$ addition could directly decrease the availability and plant uptake of $\mathrm{P}$ (Emmet et al. 1995, Gundersen 1998, Matson et al. 1999. Gradowski and Thomas (2006) described two mechanisms governing this change. The geochemical mechanism suggests that soil acidification induced by $\mathrm{N}$ deposition can result in increased $\mathrm{P}$ fixation by $\mathrm{Fe}$ and $\mathrm{Al}$ hydrous oxides, which might substantially diminish the availability of phosphate. The biological mechanism proposes that significant accumulation of soil organic matter affected by $\mathrm{N}$ deposition may reduce pools of inorganic $\mathrm{P}$ by promoting conversion to organic forms of P. Our results suggest that neither mechanism is operating at these sites. In the disturbed forest, $46 \mathrm{mo}$ of continuous $\mathrm{N}$ addition has failed to significantly affect soil $\mathrm{pH}$, extractable $\mathrm{Al}$ and Fe concentrations, and soil organic carbon content (Table 3).

Results for the rehabilitated forest, however, contradict our original hypothesis, with soil $\mathrm{P}$ availability increasing in response to $\mathrm{N}$-treatments. To our knowledge, this finding is different from any other studies (e.g., Gradowski \& Thomas 2006), although some fertilization experiments have demonstrated that adding $\mathrm{N}$ could increase the P cycling rates by increasing extracellular phosphatase activity and releasing phosphate from soil organic matter (Olander \& Vitousek 2000, Treseder \& Vitousek 2001, Gress et al. 2007). In this forest, no significant effects of $\mathrm{N}$ addition on soil acidification process and soil organic matter content were found (Table 3). Results of published studies do not offer a satisfactory explanation for changes of soil available $\mathrm{P}$ in both the disturbed and rehabilitated forests.

As discussed, recycling of $\mathrm{P}$ through biologic processes could be one dominant way to supply soil available P (Walker \& Syers 1976, Tiessen et al. 1994, and McGroddy et al. 2004b). Although there have been many studies on the response of litter decomposition to $\mathrm{N}$ addition (Knorr et al. 2005, Mo et al. 2006), information regarding the response of litterfall production to increased $\mathrm{N}$ deposition in forest ecosystems is more limited (Chappell et al. 1999, Magill et al. 2004, Kaspari et al. 2008, Pregitzer et al. 2008, Sheppard et al. 2008). Studies such as these are less common in tropical forests. Furthermore, no studies have explored possible relationships between nutrient release from decomposing litter and soil nutrient status with elevated $\mathrm{N}$ deposition. Hence, we hypothesize that both responses of litter decomposition rates and litter production to $\mathrm{N}$ addition may codominate the dynamics of soil available $\mathrm{P}$ in this study.

After the initial 26 mo of continuous $\mathrm{N}$ fertilization, further $\mathrm{N}$ addition (October 2005 to September 2006) significantly reduced $\mathrm{P}$ loss from decomposing litter in the disturbed forest.
These results are consistent with our previous study reporting that $\mathrm{N}$ addition significantly suppressed release rate of $\mathrm{P}$ from decomposing litter of $P$. massoniana in the disturbed forest in the first 24-mo (July 2003 to June 2005) of this N fertilization experiment (Mo et al. 2007), and similar to other studies in tropical forests reporting that fertilization can induce microbial nutrient retention within decomposing litter in nutrient-poor systems (McGroddy et al. 2004b, Cleveland et al. 2006). Hence, an important source of available $\mathrm{P}$ could be greatly reduced by inhibiting litter $\mathrm{P}$ release from decomposing litter. As aboveground litter production was equivalent between the Control plots and $\mathrm{N}$-treatment plots, slower rates of $\mathrm{P}$ release from decomposing litter probably decreased return of $\mathrm{P}$ to soil, thus decreasing soil available P.

In the rehabilitated forest, further $\mathrm{N}$ addition (October 2005 to September 2006) had no significant effect on loss of P from decomposing litter, although the previous results of the first 24-mo (July 2003 to June 2005) in this $\mathrm{N}$ fertilization experiment showed that $\mathrm{N}$ addition significantly suppressed release rate of $\mathrm{P}$ from decomposing litter of $P$. massoniana relative to the controls (Mo et al. 2007). Ribeiro et al. (2002) also found that $\mathrm{N}$ addition stimulated release of $\mathrm{P}$ during litter decomposition. Considering both the use of identical litter from the decomposition experiment and the $\mathrm{N}$-limited status of both disturbed and rehabilitated forests (Mo et al. 2006), attenuation of suppressing effects on litter $\mathrm{P}$ release may contribute to the increased soil available $\mathrm{P}$, as microbes typically immobilize P from soil solution during decomposition in a P-poor system (McGroddy et al. 2004b, Olander \& Vitousek 2004, Cleveland et al. 2006).

Under continual $\mathrm{N}$ addition, carbon and $\mathrm{P}$ may become a limiting factor for litter decomposition in both the disturbed and rehabilitated forests. It has been suggested that chronic $\mathrm{N}$ addition to $\mathrm{N}$-limited forests soil will initially stimulate soil microbial activity, but over time, would result in a carbon-limited state after microbial demand for $\mathrm{N}$ was satisfied (Aber et al. 1998), with fresh materials decomposing faster than older materials (Berg \& Soderstrom 1979). We have shown that $\mathrm{N}$ addition significantly increased the production of litterfall in the rehabilitated forest, e.g., at the third (September 2005 to August 2006) and fourth (September 2006 to August 2007) year of the experiment, but not in the disturbed forest (Fig. 3). These results indicate that the amount of substrate resupplied by litterfall in the N-treated plots is larger in the rehabilitated forest than in the disturbed forest under the same rate of $\mathrm{N}$ addition, suggesting that more carbon and $\mathrm{P}$ are available for soil microbial activity in the rehabilitated forest. Although $\mathrm{N}$ addition had no effect on the loss of $\mathrm{P}$ from decomposing litter in the rehabilitated forest, higher production of total litterfall probably facilitated soil $\mathrm{P}$ accumulation.

Given the central role of litter production and decomposition in determining the response of soil available $\mathrm{P}$ to $\mathrm{N}$ addition, their contrasting response patterns to $\mathrm{N}$ addition in the disturbed versus rehabilitated forests may have arisen from changes in tree species composition and soil nutrient status, brought about by different land-use practices. As mentioned, both forests originated 
from man-made pine forests. In the rehabilitated forest, after more than $70 \mathrm{yr}$ of rehabilitation, establishment of regional broadleaf species via natural dispersal has changed plant composition, which is dominated by $P$. massoniana and a few broadleaf species (mainly $S$. superba) (Mo et al. 2003). The disturbed forest, however, has been under nearly constant human pressure (generally the harvesting of understory and litter to satisfy fuel needs of local people) from time of planting until the late 1990s (Wang et al. 1982, Brown et al. 1995, Mo et al. 1995). These intensive, ongoing removals in the disturbed forest resulted in minimal remnant vegetation cover, minimized competitive interaction among understory plants, and maintained overstory dominance by $P$. massoniana by eliminating seedlings of potential dominant/ co-dominant species (Mo et al. 1995, 2003, Lu et al. 2011). Presently, the disturbed forest is dominated by pines, representing $>95$ percent of total basal area (Table 1). In contrast, the rehabilitated forest was co-dominated by pines and broadleaf trees, 40 and 60 percent relative basal area, respectively (Table 1).

Different forest land-use practices have also led to differences in soil nutrient status. Previous work showed that both forests are still $\mathrm{N}$-limited because of previous deforestation activities that led to substantial loss of soil N (Mo et al. 2003, 2006). Mo et al. (1995) have shown, however, that harvest practices in the disturbed forest removed about 44-73 percent of the total quantity nutrients in the litter and understory production, an amount that appeared to exceed most nutrient input from atmospheric deposition. Mo et al. (2003) further suggested that successful resupply of soil nutrients (e.g., available soil $\mathrm{N}$ ) in the rehabilitated forests is possible, but not in the disturbed forest because of continued harvest practices.

Contrasting plant species and nutrient status may lead to the differences in plant growth and litterfall production between the two forests. Lu et al. (2011) suggested that low soil $\mathrm{N}$ and nutrient status may hinder the growth of the trees in the disturbed forest. The slow growth and low nutrient turnover rates of P. massoniana, even at high $\mathrm{N}$ inputs, may result in no significant changes of plant growth (e.g., canopy closure) during the study period ( $\mathrm{Lu}$ et al. 2011). In the rehabilitated forest, successful restoration of soil nutrients on severely degraded lands might be possible (Mo et al. 2003), and $\mathrm{N}$ addition was shown to increase plant growth (Lu et al. 2011). Hence, we hypothesize that the increased litterfall could be the result of greater plant growth with $\mathrm{N}$ addition in the rehabilitated forest.

In conclusion, our results suggest that continued $\mathrm{N}$ addition can affect soil $\mathrm{P}$ availability in reforested regions of southern China, but that this response may vary greatly with overstory tree species composition and soil nutrient status as influenced by land-use practices. In the disturbed forest, the significant decrease of soil available $\mathrm{P}$ under $\mathrm{N}$-treatments may be the result of the significant suppressing of $\mathrm{P}$ release in the absence of change in litter production. In contrast, the rehabilitated forest showed that $\mathrm{N}$ addition significantly increased available soil $\mathrm{P}$, an increase that contributed to higher litter production and attenuation of suppressing effects on release of litter P. This study provides new insights on how elevated $\mathrm{N}$ deposition affects $\mathrm{P}$ availability, with potential applications toward ecosystem health and services. Increases in available soil $\mathrm{P}$ in the rehabilitated forest have implications for the potential effectiveness of increased $\mathrm{P}$ in reducing the symptoms of $\mathrm{N}$ saturation in the future. Our results were evaluated for just one site of each forest type; thus, applications of our results to other reforested forests in southern China should be made with caution. Indeed, confirmation of our results will require further investigation in other regions.

\section{ACKNOWLEDGMENTS}

We thank the subject editor and the two anonymous reviewers for their valuable comments and suggestions on the manuscript, and Drs. Sandra Brown, Per Gundersen, Guirui Yu, and Linghao $\mathrm{Li}$ for their invaluable suggestions on the earlier version of the paper. This study was funded by the National Basic Research Program of China (2010CB833502), National Natural Science Foundation of China (No. 30970521, 30900202), Natural Science Foundation of Guangdong Province, China (Grant 8351065005000001), and the Knowledge Innovation Program of the Chinese Academy of Sciences (Grant No.KSCX2-EW-J-28).

\section{LITERATURE CITED}

Aber, J. D., W. McDowell, K. J. Nadelhoffer, A. Magill, G. Berntson, M. Kamakea, S. G. McNulty, and W. Currie. 1998. Nitrogen saturation in northern forest ecosystems: hypotheses revisited. Bioscience. 48: 921-933.

Avis, P. G., D. J. Mclaughlin, B. C. Dentinger, and P. B. Reich. 2003. Long-term increase in nitrogen supply alters above- and below-ground ectomycorrhizal communites and increases the dominance of Russula spp. in a temperate oak savanna. New Phytol. 160: 239-253.

Berg, B., And B. Soderstrom. 1979. Fungal biomass and nitrogen in decomposing scots pine needle litter. Soil Biol. Biochem. 11: 339-341.

Bobbink, R., K. Hicks, J. Galloway, T. Spranger, R. Alkemade, M. Ashmore, M. Bustamante, S. Cinderby, E. Davidson, F. Dentener, B. Emmett, J. W. Erisman, M. Fenn, F. Gilliam, A. Nordin, L. Pardo, and W. De VRIES. 2010. Global assessment of nitrogen deposition effects on terrestrial plant diversity effects of terrestrial ecosystems: a synthesis. Ecol. Appl. 20: 30-59.

Braun, S., V. F. D. Thomas, R. Quiring, and W. Flückiger. 2010. Does nitrogen deposition increase forest production? The role of phosphorus. Environ. Pollut. 158(6): 2043-2052.

Bray, R. H., AND L. T. Kurtz. 1945. Determination of total organic and available forms of phosphorus in soils. Soil Sci. 59: 39-45.

Brown, S., M. T. Lenart, J. M. Mo, and G. H. Kong. 1995. Structure and organic matter dynamics of a human-impacted pine forest in a MAB reserve of subtropical China. Biotropica. 27: 276-289.

Chappell, H. N., C. E. Prescott, and L. Vesterdal. 1999. Long-term effects of nitrogen fertilization on nitrogen availability in Coastal Douglas-fir forest floors. Soil Sci. Soc. Am. J. 63: 1448-1454.

Cleveland, C. C., And A. R. Townsend. 2006. Nutrient additions to a tropical rain forest drive substantial soil carbon dioxide losses to the atmosphere. Proc. Natl Acad. Sci. U.S.A., 103: 10316-10321.

Cleveland, C. C., S. C. Reed, And A. R. Townsend. 2006. Nutrient regulation of organic matter decomposition in a tropical rain forest. Ecology. 87: 492-503.

Corre, M. D., E. Veldkamp, J. Arnold, and S. J. Wright. 2010. Impact of elevated $\mathrm{N}$ input on soil $\mathrm{N}$ cycling and losses in lowland and montane forests in Panama. Ecology. 91(6): 1715-1729. 
Cusack, D. F., W. L. Silver, M. S. Torn, and W. H. McDowell. 2011. Effects of nitrogen additions on above-and belowground carbon dynamics in two tropical forests. Biogeochemistry. 104: 203-225.

Davidson, E. A., C. J. Reis de Carvahlo, A. M. Figueira, F. Y. Ishida, J. P. H. B. Ometto, G. B. Nardoto, R. T. Sabá, S. N. Hayashi, E. C. Leal, I. C. G Vieira, And L. A. Martinelli. 2007. Recuperation of nitrogen cycling in Amazonian forests following agricultural abandonment. Nature. 447: 995-999.

Dong, M. (Eds.). 1996. Survey, observation and analysis of terrestrial biocommunities. Chinese Standards Press, Beijing.

Emmet, B. A., P. A. Stevens, and B. Reynolds. 1995. Factors influencing nitrogen saturation in Sitka spruce stands in Wales, UK. Water Air Soil Pollut. 85: 1629-1634.

Fang, H., J. M. Mo, S. L. Peng, Z. A. Li, and H. Wang. 2007. Cumulative effects of nitrogen additions on litter decomposition in the three tropical forests in southern China. Plant Soil. 297: 233-242.

Fang, Y. T., P. Gundersen, J. M. Mo, And W. X. Zhu. 2008. Input and output of dissolved organic and inorganic nitrogen in subtropical forests of South China under high air pollution. Biogeosciences. 5: 339-352.

Fujita, Y., B. J. M. Robroek, P. C. De Ruiter, G. W. Heil, and M. J. Wassen. 2010. Increased $N$ affects $P$ uptake of eight grassland species: the role of root surface phosphatase activity. Oikos. 119: 1665-1673.

Galloway, J. N., F. J. Dentener, D. G. Capone, E. W. Boyer, R. W. Howarth, S. P. Seitzinger, G. P. Asner, C. C. Cleveland, P. A. Green, E. A. Holland, D. M. Karl, A. F. Michaels, J. H. Porter, A. R. Townsend, and C. J. Vorosmarty. 2004. Nitrogen cycles: past, present, and future. Biogeochemistry. 70: 153-226.

Gilliam, F. S. 2006. Response of the herbaceous layer of forest ecosystems to excess nitrogen deposition. J. Ecol. 94: 1176-1191.

Gradowski, T., And S. C. Thomas. 2006. Phosphorus limitation of sugar maple growth in central Ontario. For. Ecol. Manag. 226: 104-109.

Gress, S. E., T. D. Nichols, C. C. Northcraft, and W. T. Peterjohn. 2007. Nutrient limitation in soils exhibiting differing nitrogen availabilities: what lies beyond nitrogen saturation? Ecology. 88: 119-130.

Gundersen, P. 1998. Effects of enhanced nitrogen deposition in a spruce forest in Klosterhede, Denmark, examined by moderate $\mathrm{NH}_{4} \mathrm{NO}_{3}$ addition. For. Ecol. Manag. 101: 251-268.

Holdridge, L. R. 1967. Life zone ecology. Tropical Science Center, San Jose, Costa Rica.

Harrold, S. A., And M. A. TABatabai. 2006. Release of inorganic phosphorus from soils by low-molecular-weight organic acids. Comm Soil. Sci Plant Anal. 37: 1233-1245.

Huang, Z. F., And Z. G. Fan. 1982. The climate of Ding Hu Shan. Trop. Subtrop. For. Ecosyst. 1: 11-23. (in Chinese with English abstract).

Hunang, Z. L., M. M. Ding, Z. P. Zhang, And W. M. Y. 1994. The hydrological processes and nitrogen dynamics in a monsoon evergreen broad-leafed forest of Dinghu shan. Acta Phytoecol. Sinica. 18: 194-199 (in Chinese with English abstract).

Hurlbert, S. H. 1984. Pseudoreplication and the design of ecological field experiments. Ecol. Monogr. 54: 187-211.

Kaspari, M., M. N. Garcia, K. E. Harms, M. Santana, S. J. Wright, and J. B. Yaviтt. 2008. Multiple nutrients limit litterfall and decomposition in a tropical forest. Ecol. Lett.. 11: 35-43.

Knorr, M., S. D. Frey, And P. S. Curtis. 2005. Nitrogen additions and litter decomposition: a meta-analysis. Ecology. 86: 3252-3257.

Kuperman, R. G. 1999. Litter decomposition and nutrient dynamics in oakkickory forests in the Netherlands. Soil Biol. Biochem. 31: 237-244.

Lebauer, D. S., And K. K. Treseder. 2008. Nitrogen limitation of net primary productivity in terrestrial ecosystems is globally distributed. Ecology. 89: 371-379.

LI, W. 2004. Degradation and restoration of forest ecosystems in China. For. Ecol. Manag. 201: 33-41.

Liv, G. H., B. J. Fu, L. D. Chen, And X. D. Guo. 2000. Characteristics and distributions of degraded ecological types in China. Acta Ecol. Sinica. 20: 13-19 (in Chinese with English abstract).
Liu, G. S., N. H. Jiang, L. D. Zhang, and Z. L. Liu. 1996. Soil physical and chemical analysis and description of soil profiles, pp. 121-265. Standards Press of China, Beijing (in Chinese).

Liu, X., L. Duan, J. Mo, E. Du, J. Shen, X. Lu, Y. Zhang, X. Zhou, C. He, AND F. ZhANG. 2011. Nitrogen deposition and its ecological impact in China: an overview. Environ. Pollut. 159: 2251-2264.

LÜ, C. Q., And H. Q. Tian. 2007. Spatial and temporal patterns of nitrogen deposition in China: synthesis of observational data. J. Geophys. Res. 112: D22S05, doi: 10.1029/2006JD007990.

Lu, X. K., J. M. Mo, P. Gundersen, W. X. Zhu, G. Y. Zhou, D. J. Li, And X. ZHANG. 2009. Effect of simulated $\mathrm{N}$ deposition on soil exchangeable cations in three forest types of subtropical China. Pedosphere. 19 (2): 189-198.

Lu, X., J. Mo, F. S. Gildiam, G. Zhou, and Y. Fang. 2010. Effects of experimental nitrogen deposition on plant diversity in an old-growth tropical forest. Glob. Change Biol. 16: 2688-2700.

Lu, X., J. Mo, F. S. Gilliam, G. Yu, W. Zhang, Y. Fang, and J. Huang. 2011. Effects of experimental nitrogen additions on plant diversity in tropical forests of contrasting disturbance regimes in southern China. Environ. Pollut. 159: 2228-2235.

McCormick, L. H., AND Y. Borden. 1972. Phosphate fixation by aluminium in plant roots. Soil Sci. Soc. Am. Proc. 36: 799-802.

Magill, A. H., J. D. Aber, W. S. Currie, K. J. Nadelhoffer, M. E. Martin, W. H. Mcdowell, J. M. Melillo, And P. A. Steudler. 2004. Ecosystem response to 15 years of chronic nitrogen additions at the Harvard Forest LTER, Massachusetts, USA. For. Ecol. Manag. 196: 7-28.

Matson, P. A., W. H. Mcdowell, A. R. Townsend, and P. M. Vitousek. 1999. The globalization of $\mathrm{N}$ deposition: ecosystem consequences in tropical environments. Biogeochemistry. 46: 67-83.

Matson, P., K. Lohse, and S. Hall. 2002.The globalization of nitrogen: consequences for terrestrial ecosystems. Ambio. 31: 113-119.

May, J. D., E. Burdette, F. S. Gilliam, and M. B. Adams. 2005. Interspecific divergence in foliar nutrient dynamics and stem growth in a temperate forest in response to chronic nitrogen inputs. Can. J. For. Res. 35: 1023-1030.

McGroddy, M. E., T. Daufresne, and L. O. Hedin. 2004a. Scaling of C:N:P stoichiometry in forests worldwide: implications of terrestrial Redfieldtype ratios. Ecology. 85: 2390-2401.

McGroddy, M. E., W. L. Silver, And R. C. Oliveira Jr. 2004b. The effect of phosphorus availability on decomposition dynamics in a seasonal lowland Amazonian forest. Ecosystem. 7: 172-179.

Mo, J. M., S. Brown, M. Lenart, and G. H. Kong. 1995. Nutrient dynamics of a human-impacted pine forest in a MAB reserve of subtropical China. Biotropica. 27: 290-304.

Mo, J. M., Y. T. Fang, D. Q. Zhang, G. H. Kong, and Z. N. Fen. 2002. Effects of rainfall reallocation on nutrient dynamic of a pine forest in Dinghushan. Guihaia. 22: 529-533 (in Chinese with English abstract).

Mo, J. M., S. Brown, S. L. Peng, and G. H. Kong. 2003. Nitrogen availability in disturbed, rehabilitated and mature forests of tropical China. For. Ecol. Manag. 175: 573-583.

Mo, J. M., S. Brown, J. H. Xue, Y. T. Fang, and Z. A. Li. 2006. Response of litter decomposition to simulated $\mathrm{N}$ deposition in disturbed, rehabilitated and mature forests in subtropical China. Plant Soil. 282: 135-151.

Mo, J. M., S. Brown, J. H. Xue, Y. T. Fang, Z. A. Li, D. J. Li, and S. F. Dong. 2007. Response of nutrient dynamics of decomposing pine (Pinus massoniana) needles to simulated $\mathrm{N}$ deposition in a disturbed and rehabilitated forest in tropical China. Ecol. Res. 22: 649-658.

Olson, J. S. 1963. Energy storage and the balance of producers and decomposers in ecological systems. Ecology. 44: 322-331.

Olander, L. P., And P. M. Vitousek. 2000. Regulation of soil phosphatase and chitinase activity by $\mathrm{N}$ and $\mathrm{P}$ availability. Biogeochemistry. 49: $175-190$.

Olander, L. P., And P. M. Vitousek. 2004. Biological and geochemical sinks for phosphorus in soil from a wet tropical forest. Ecosystems. 7: 404419. 
Percy, K. E., And M. Ferretti. 2004. Air pollution and forest health: towards new monitoring concepts. Environ Pollut., 130: 113-126.

Pregitzer, K. S, A. J. Burton, D. R. Zak, and A. F. Talhelm. 2008. Simulated chronic nitrogen deposition increases carbon storage in Northern Temperate forests. Glob. Change Biol. 14: 142-153.

Ribeiro, C., M. Madeira, and M. C. Araújo. 2002. Decomposition and nutrient release from leaf litter of Eucalyptus globules grown under different water and nutrient regimes. For. Ecol. Manag. 171: 31-41.

Reich, P. B., And J. Oleksyn. 2004. Global patterns of plant leaf N and P in relation to temperature and latitude. Proc. Nat. Acad. Sci. 101(30): 11001-11006.

Reiners, W. A. 1986. Complementary models for ecosystems. Am. Nat. 127: $59-73$.

Sala, O. E., F. S. Chapin III, J. J. Armesto, E. Berlow, J. Bloomfield, R. Dirzo, E. Huber-Saniwald, L. F. Huenneke, R. B. Jackson, A. Kinzig, R. Leemans, D. M. Lodge, H. A. Mooney, M. Oesterheld, N. L. Poff, M. T. Sykes, B. H. Walker, M. Walker, and D. H. WALL. 2000. Global biodiversity scenarios for the year 2100 . Science. 287: 1770-1774.

SCHLEsinger, W. 1997. Biogeochemistry: an analysis of global change (2nd Edition), 588 pp. Academic Press, San Diego, CA.

SFA (State Forestry Administration). 2007. China's Forestry 1999-2005. China Forestry Publishing House, Beijing.

Sherman, J., I. J. Fernandez, S. A. Norton, T. Ohno, and L. E. Rustad. 2006. Soil aluminum, iron, and phosphorus dynamics in response to long-term experimental nitrogen and sulfur additions at the Bear Brook watershed in Maine, USA. Environ. Monit. Assess. 121: 421-429.

Sheppard, L. J., A. Crossley, K. Ingleby, and C. Woods. 2008. Implications of acidified $\mathrm{S}$ inputs on the fate and consequences of $\mathrm{N}$ deposition: results from a field manipulation of a Sitka spruce canopy in southern Scotland. Int. J. Environ. Stud. 65: 409-430.

Singh, C. P., And A. Amberger. 1998. Organic acids and phosphorus solubilization in straw composted with rock phosphate. Bioresour. Technol. 63: $13-16$.

Treseder, K. K., And P. M. Vitousek. 2001. Effects of soil nutrient availability on investment in acquisition of $\mathrm{N}$ and $\mathrm{P}$ in Hawaiian rain forests. Ecology. 82: 946-954.

Tiessen, H., E. Cuevas, And P. Chacon. 1994. The role of soil organic matter in sustaining soil fertility. Nature. 371: 783-785.
Thomas, R. Q., C. D. Canham, K. C. Weathers, and C. L. Goodale. 2010. Increased tree carbon storage in response to nitrogen deposition in the U.S. Nat. Geosci. 3: 13-17.

Van Groenigen, K. J., J. Six, B. A. Hungnate, M. A. De Graaff, N. Breemen, and C. Van Kessel. 2006. Element interactions limit soil carbon storage. Proc. Natl Acad. Sci. U.S.A. 103: 6571-6574.

Vesterdal, L., And K. Raulund-Rasmussen. 2002. Availability of nitrogen and phosphorus in Norway spruce forest floors fertilized with nitrogen and other essential nutrients. Soil Biol. Biochem. 34: 12431251.

VitouseK, P. M. 1984. Litterfall, nutrient cycling and nutrient limitation in tropical forest. Ecology. 65: 285-298.

Vitousek, P. M. 1998. Foliar and litter nutrients, nutrient resorption, and decomposition in Hawaiian Metrosideros polymorpha. Ecosystems. 1: 401-407.

Vitousek, P. M., S. Porder, B. Z. Houlton, and O. A. Chadwick. 2010. Terrestrial phosphorus limitation: mechanisms, implications, and nitrogen-phosphorus interactions. Ecol. Appl. 20(1): 5-15.

Walker, T. W., AND J. K. Syers. 1976. The fate of phosphorus during pedogenesis. Geoderma. 15: 1-19.

Wang, Z., D. He, S. Song, S. Chen, D. Chen, and M. Tu. 1982. The vegetation of Dinghushan biosphere reserve. Trop. Subtrop. For. Ecosyst. 1: 77-141 (in Chinese with English abstract).

Weand, M. P., M. A. Arthur, G. M. Lovett, F. Sikora, and K. C. Weathers. 2010. The phosphorus status of northern hardwoods differs by species but is unaffected by nitrogen fertilization. Biogeochemistry. 97: 159-181.

Zak, D. R., W. E. Holmes, A. J. Burton, K. S. Pregitzer, And A. F. Talmelm. 2008. Simulated atmospheric $\mathrm{NO}_{3}{ }^{-}$deposition increases soil organic matter by slowing decomposition. Ecol. Appl. 18: 2016-2027.

Zhou, G. Y., AND J. H. Yan. 2001. The influence of region atmospheric precipitation characteristics and its element inputs on the existence and development of Dinghushan forest ecosystems. Acta Ecol. Sinica. 21: 2002-2012 (in Chinese with English abstract).

Zou, X. M., D. Binkiey, and B. Caldwell. 1995. Effects of dinitrogen fixing trees on phosphorus biogeochemical cycling in contrasting forests. Soil Sci. Soc. Am. J. 59: 1452-1458. 